\section{ISSN 0376-8929}

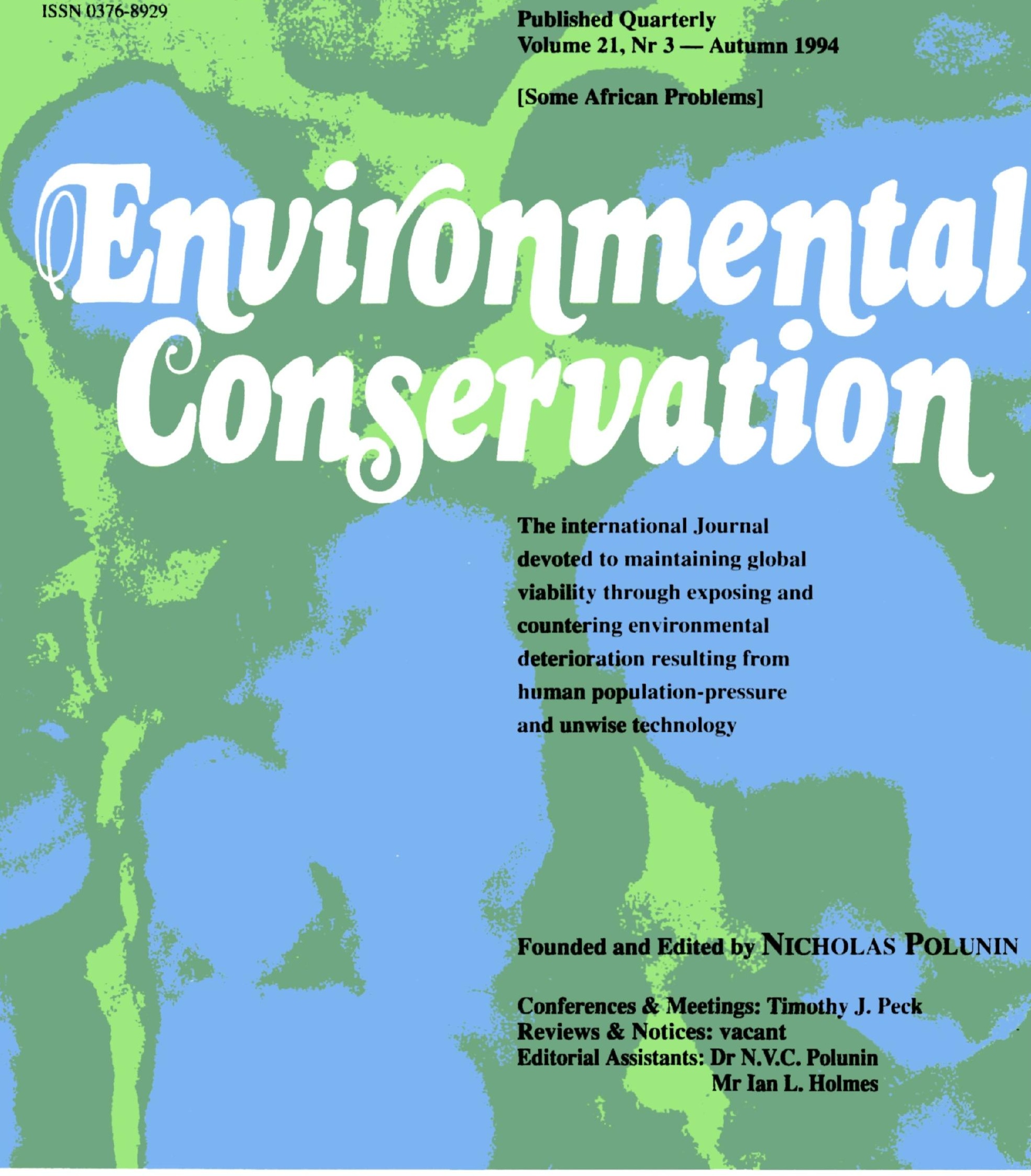

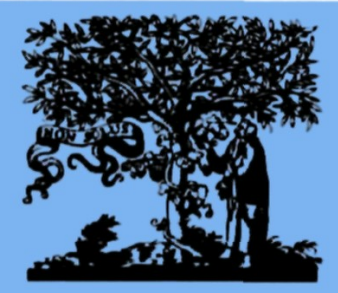

Distributed for the

FOUNDATION

FOR ENVIRONMENTAL

CONSERVATION

$$
\text { by }
$$

ELSEVIER SCIENCE

Lausanne, Switzerland $\theta$

the collaboration of the

United Nations Environment Programme (UNEP)

MUCN World Conservation Union (IUCN)

International Association for Ecology (INTECOL)

International Conferences on Environmental Future (ICEFs)

Worid Council For The Biosphere-International Society For

Environmental Education (WCB-ISEE)

World Wide Fund for Nature (WWF)

$1 \%$ international Society of Naturalists (INSONA) 


\section{Genvironmental Conservation}

advocates timely action for the protection and amelioration of the environment of Mankind and Nature throughout the world. Topics range from pertinent case-histories of the past and present to rational use of resources, foreseeing ecological consequences, enlightened environmental policy, anti-pollution measures, low-impact development, environmental education and law, and ecologically sound management of all land and fresh water, sea and air, for the lasting future of Earth's fragile Biosphere.

The following are the main types of contributions which may be accepted for publication in this Journal:

Policy-advocating leaders on outstanding topics;

Survey articles on important aspects of its subject;

Research papers whether basic or 'confirmatory';

Case-history accounts of wide significance and interest;

$$
\&
$$

Items for the following five regular sections:

Editorial Section: Usually including an Editorial or Guest

Editorial, Guest Comment or Comments, and Notice or

Notices most commonly about Available Publications;

Short Communications \& Reports (SCRs); normally not exceeding three pages of the Journal each in length;
Notes, News \& Comments (NNCs): preferably at most one page of the Journal each;

Conferences \& Meetings ( $C \& M s)$; summary reports, Important Prospects; and

Reviews \& Notices ( $R \& N s)$ : of new books etc.

Founded in 1974 and Edited by Nicholas Polunin Conferences \& Meetings: Timothy J. Peck

Reviews \& Notices: vacant

Editorial Assistants: Dr N.V.C. Polunin

Mr Ian L. Holmes

\section{ADVISORY EDITORS}

African Developments: Senator Prof. Mohamed Kassas (Cairo, Egypt) Animal Ecology: Prof. Raymond F. Dasmann (Santa Cruz, California, USA)

Animal Impact: Prof. Jean Dorst (Paris, France)

Australasia: Dr Donald F. McMichael (Canberra City, Australia)

Biological Productivity: Dr E. Barton Worthington (Nr Uckfield, England, UK)

Biosphere Maintenance: Prof. Hon. Beatrice E. Willard (Boulder, Colorado, USA)

Central America: Dr Anne LaBastille (Big Moose, NY, USA)

China: Dr Chi Yung Jim (Hong Kong)

Climatic Variation: Chancellor F. Kenneth Hare (Toronto, Ontario, Canada)

Coastal Ecology: Dr N.V.C. Polunin (Newcastle, England, UK)

Conservation Evaluation: Prof. Michael B. Usher (Edinburgh, Scotland, UK)

Conservation Policy: Prof. M.E. Duncan Poore (Invermess, Scotland, UK)

Economic Aspects: Prof. Marshall I. Goldman (Cambridge, Massachusetts, USA)

Ecosystems Research: Prof. Eugene P. Odum (Athens, Georgia, USA)

Education and Training: Prof. William B. Stapp (Ann Arbor, Michigan, USA)

Endangered Biota and Ecosystems: Prof. Norman Myers (Oxford, England, UK)

Energy: Prof. John P. Holdren (Berkeley, California, USA)

Environmental Engineering: Prof. Philip H. Jones (Brisbane, Australia)

Environmental Law: Prof. Christopher D. Stone (Los Angeles, California, USA)

Ethnobotanical Conservation: Prof. Richard E. Schultes (Cambridge, Massachusetts, USA)

Fresh Waters: Prof. Gilbert F. White (Boulder, Colorado, USA)

Geographical Aspects: Prof. Andrew S. Goudie (Oxford, England, UK)

Human Behaviour: Dr Ivan Polunin (Singapore)

Human Rights: Ambassador Hannu Halinen (Helsinki, Finland)

Indian-Malaysian Wildlife: Prof. Gunavant M. Oza (Baroda, India)

INTECOL: Prof. Frank B. Golley (Athens, Georgia, USA)

International Wildlife Conservation: Jeffrey A. McNeely (Gland, Switzerland)
Island Ecosystems: vacant to our great loss and deep regret

IUCN: vacant

Marine Waters: Prof. G. Carleton Ray (Charlottesville, Virginia, USA)

Medical Aspects: Dr Bent Juel-Jensen (Oxford, England, UK)

Meteorology and Climatology: Prof. Reid A. Bryson (Madison, Wisconsin, USA)

Microbiological Implications: Prof. Samir l. Ghabbour (Cairo, Egypt)

Military and Training Aspects: Dr Arthur H. Westing (Putney, Vermont, USA)

Ornithological Aspects: Dr Christoph Imboden (Cambridge, England, UK)

Parks and Reserves: Dr James W. Thorsell (Gland, Switzerland)

Pesticides and Toxicants: Dr Daniel Osborn (Abbots Ripton, England, UK)

Plant Ecology: Prof. Makoto Numata (Chiba, Japan)

Plant Physiology: Prof. Terence A. Mansfield (Lancaster, England, UK)

Pollutants and Disposal: Prof. Kenneth Mellanby (Cambridge, England, UK)

Population Impact: Prof. Paul R. Ehrlich (Stanford, California, USA)

Resources Conservation: Prof. S. Fred Singer (Charlottesville, Virginia, USA)

Social Studies: Prof. Lynton K. Caldwell (Bloomington, Indiana, USA)

Soils and Erosion: Prof. Vladimir P. Bashkin (Pushchino, Russia)

South America: HE Prof. Paulo Nogueira-Neto (São Paulo, Brazil)

South-Fast Asia: Prof. 'Otto' Soemarwoto (Bandung, Indonesia)

South-West Asia: Christopher D.W. Savage (Petworth, England. UK)

Tourism \& Recreation: Prof. Richard W. Butler (London, Ontario, Canada)

UNEP: vacant

WCB-ISEE: Prof. Craig B. Davis (Columbus, Ohio, USA)

West Africa: Dr Emmanuel O.A. Asibey (Washington DC \& Accra, Ghana) WWF: Dr Claude Martin (Gland, Switzerland)

\section{SUBMISSION OF MANUSCRIPTS}

All contributions must be in precise English and original, submission of a manuscript implying that it is unpublished and is not being considered contemporaneously for publication elsewhere. Manuscripts (three copies, including one or two on light airmal paper) and allied materials should be sent to:

Prof. Dr Nicholas Polunin, Editor

ENVIRONMENTAL CONSERVATION

7 Chemin Taverney

1218 Grand-Saconnex

Geneva, Switzerland or to one of the Advisory Editors (listed above). There is a set of Instructions for Authors on the inside of the back cover of each issue: failure to follow these in reasonable degree may lead to, at best, protracted correspondence or return of a manuscript for restyling before it can be considered or even refereed.

\section{PUBLISHING AND SUBSCRIPTION INFORMATION}

Environmental Conservation is published by Elsevier Science SA Lausanne, Switzerland, for the Foundation for Environmental Conservation, with the collaboration of the United Nations Environment Programme (UNEP), the World Conservation Union (IUCN), the International Association for Ecology (INTECOL), the International Society of Naturalists (INSONA), International Conferences on Environmental Future (ICEFs), World Council For The Biosphere-International Society For Environmental Education (WCB-ISEE), World Wide Fund for Nature (WWF), and others. It is covered in numerous international indexing or abstracting journals emanating particularly from the United Kingdom, the United States, Italy, and Germany.

Environmental Conservation is published quarterly, correspondingly to the year's four seasons in the Northern Hemisphere.
Size $27.5 \times 20 \mathrm{~cm}$, comprising usually 384 pages (with additional covers, etc.) per annum. The volume subscription price for 1994 is SFr. 290 or US $\$ 197$ (including SFr. 50 for handling and postage) subscribers in the following countries receive their copies by airmail at no extra charge: Australia, Brazil, Canada, China, Hong Kong, India, Israel, Japan, Malaysia, New Zealand, Pakistan, Singapore, South Africa, South Korea, Taiwan, and USA.

Subscription orders and inquiries should be sent to:

ENVIRONMENTAL CONSERVATION

Elsevier Science

PO Box 564

1001 Lausanne 1

Switzerland. 